\title{
ANALYSIS OF SLOPE STABILITY FOR KAANDE LANDSLIDE OF PHEWA WATERSHED, POKHARA, NEPAL
}

\author{
Keshav Basnet ${ }^{1, *}$, Dhruba Wagle ${ }^{1}$, Sagar Bhattarai ${ }^{1}$, and Biwas Babu Sadadev ${ }^{1}$ \\ ${ }^{1}$ Department of Civil and Geomatics Engineering, Pashchimanchal Campus, Institute of Engineering, \\ Tribhuvan University, Pokhara, Nepal \\ *E-mail: basnet.keshav@gmail.com; ORCID 0000-0001-8145-9654
}

\begin{abstract}
Phewa watershed of Kaski, Nepal is constantly facing landslides and soil erosion problems. Andheri Khola sub-basin of Phewa watershed accounts the maximum amount of sediment inflow into Phewa Lake. Therefore Kaande Landslide of Andheri Khola sub-basin, located between Deurali and Paundur villages at the source zone of Andheri Khola is chosen for the slope stabilization to control the sediment flow. The main objective of the study was to analyze the slope stability condition of the landslide area for which the whole landslide area was divided into eight zones starting from the crown to the toe based on the major parameters like soil/rock type, slope inclination, spring source and surface water on the basis of field observation. The factor of safety of each zone was calculated based on stability analysis of an infinite slope of cohesive soils. Sieve analysis result shows the landslide area has coarse grained structure (gravel and sand) dominant. The factor of safety of the landslide was found to be from 0.281 to 0.710 . The field assessment and factor of safety reveals the Kaande landslide to be unstable and further possibilities of landslides and soil erosion in the future. For mitigating the hazard, eco-friendly soil bio-engineering measures such as direct seeding of grasses/shrubs, grasses/shrubs/trees plantation, brush layering, and gabion wire bolster cylinders are recommended for slope stabilization based on the optimal techniques guidelines of Mercy Corps Nepal, 2014. It is recommended to apply the proposed mitigation measures as early as possible to prevent the further landslide hazard.
\end{abstract}

\section{Keywords}

Draught, hazard, landslide, slope stability, soil bio-engineering.

\section{Introduction}

Kaski is the area of high intensity of rainfall throughout the year in Nepal (Basnet and Acharya, 2019). It receives heavy rainfall during the monsoon period i.e. June to September. During this Period, the average precipitation in this area is about $80 \%$ of total annual precipitation. Pokhara valley in Kaski receives the highest amount of annual rainfall as a result of the strong orographic effect of Annapurna Himalayan Range (Dahal and Hasewaga, 2008). This is also a reason of frequent landslide occurrence in the Phewa watershed that required the slope stability analysis and mitigating measures of the area. The present study was performed for the Kaande landslide located in 
Kaski district. The study area for this research work covers the Kaande landslide located at the source zone of Andheri Khola situated at North West part of Phewa watershed of Kaski district of Gandaki Province, Nepal.

Phewa Lake is the second largest lake in the country. Kaande Landslide in Andheri Khola sub-basin is due to the highly weathered unstable rock mass. At the initial stage gully formation was observed in the landslide area which ultimately triggered large landslide, destroying almost one lakh square meter area of forest. Sediments from landslide area is transported to the Phewa Lake by Harpan khola and the quantities of sediment transportation is even higher during monsoon. According to Pokharel (2008), the area of lake has reduced from $10 \mathrm{~km}^{2}$ in 1957 to $5.5 \mathrm{~km}^{2}$ in 1976 and to $4.4 \mathrm{~km}^{2}$ in 1998 with the shrinkage rate of 2ha/ $\mathrm{yr}$, and this decline was blamed to sediment load from upstream parts. It is necessary to stabilize the existing unstable mass and protect soil erosion in the landslide area to reduce the sediment flow in Fewa Lake. The mountainous terrain, heavy and prolonged rainfall, as well as rural road construction in steep hillsides make Phewa watershed as one of the most vulnerable areas to the risk of landslides. Kaande landslide is the largest landslide of Andheri Khola subbasin and it is still in active stage. The main objective of the study was to analyze the slope stability condition of the landslide area.

\section{Description of the Study Area}

Phewa Lake watershed extends between $28^{\circ} 11^{\prime} 39^{\prime \prime}$ North to $28^{\circ} 17^{\prime} 25^{\prime \prime}$ North latitude and $83^{\circ} 47^{\prime} 51^{\prime \prime}$ East to $83^{\circ} 59^{\prime} 17^{\prime \prime}$ East longitude. The slide area lies between Deurali and Paundur villages at the source zone of Andheri Khola and is known as Kaande Landslide. Kaande landslide is the largest landslide of Andheri Khola sub-basin and it is still in active stage. Therefore, Kaande landslide of Andheri Khola sub-basin of Phewa watershed (Figure 1) is chosen for the slope stability analysis and mitigating measures. The crown part of landslide near road has altitude of $1879.851 \mathrm{~m}$ (amsl) along with latitude $28^{\circ} 16^{\prime} 40^{\prime \prime}$ North and longitude $83^{\circ} 48^{\prime} 43^{\prime \prime}$. The elevation at toe part of the landslide is $1582.727 \mathrm{~m}$. The area is located geologically in the Lesser Himalaya, Western Nepal, and just south of the Main Central Thrust (MCT). The area is mainly composed of intercalation of quartzite and phyllite rocks. Fractured rocks are found. The quartzite is represented by presence of milky white, fine to medium-grained, rippled quartzite and phyllite is represented by thick bedded green to greenish grey phyllite. Sandy gravels are distributed in the hill slope. Loose unconsolidated sediments are also found along the slope.

The climatic condition of the study area is warm and temperate. The summers have a good deal of rainfall, while the winters have very little. Like other parts of Nepal, the region is also influenced by monsoon climate. The winter precipitation in the basin occurs from December to February. The basin is influenced by monsoon climate. It is a high precipitation zone with above $1000 \mathrm{~mm} /$ month during July and August whereas there is less than $20 \mathrm{~mm} /$ month rainfall during the dry periods of the year.

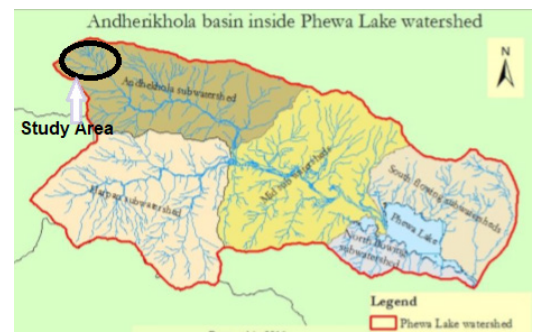

Figure 1: Study area in Phewa Lake watershed 


\section{Methodology}

\subsection{Data Used}

The information that was required includes geological, geotechnical, surface water and subsurface water. These information was available from field test, site investigation, geological mapping and from various relevant literatures.

\section{Primary Data}

- Three soil samples from each zone were collected along the slope for laboratory testing.

- Slope geometry such as slope length and slope angle was measured in the field.

- Global Positioning System (GPS) was used to obtain the coordinate of the study area.

- Existing vegetations in the study area was observed, noted and verified from the locals.

\section{Secondary Data}

- The Digital data (all layers) of Topo Grid No. 288312 of Kaski district was obtained from Department of Survey, Min Bhawan, Kathmandu, Nepal.

- Landslide reports and related documents were collected from Department of Water Induced Disaster Management Division, Pulchowk, Lalitpur, Nepal.

- Google Earth images were used for landslide inventory.

- Geological and Hydrological data were collected from literatures.

\subsection{Approach Towards the Study}

The desk study was carried out to gather as much information on the landslides as possible. Different reports, existing data and Google Earth images related to slope stability analysis were studied to obtain different parameters of the study area. The collected information/data were reviewed for planning of further field survey and investigation works as well as design for mitigation measures against landslide. Slope stability analysis was conducted using stability analysis of an infinite slope of cohesive soils with consideration of steady seepage along the slope.

Field visits were made in 2017 and 2018 to explore the study area and also to ascertain information regarding the parameters of the study area along with identification and verification of the location of landslide. Similarly, the situation of land use pattern, rural road conditions and condition of settlement was explored during the visit. The whole landslide area has been divided into different zones starting from the crown to the toe based on the parameters like soil/rock type, slope inclination, spring source, surface water etc. on the basis of field observation. The verification of the preliminary results obtained from satellite image was carried out. During this period of fieldwork, engineering geological investigations were carried out. These investigations include measurement of slope angle, slope length, verification of slope aspect, measurement of altitude, soil/rock observation etc. Soil samples were collected from each zone for laboratory testing.

The landslide is of complex type, with different types of movement at different parts. In order to ease the study, the whole landslide mapping were done and segmented to different zones on the basis of visual observation from the crown to the toe. Being different nature of slope conditions, soil/rock properties and for the application of engineering mitigation measures, entire landslide area has been divided into eight different zones. The zonation has been done starting from the crown to the toe based on the parameters like soil/rock type, slope angle, failure mechanism, 
spring source, surface flow etc.

The soil samples were tested in the laboratory to evaluate the particle size distribution, moisture content, saturated and submerged density, and shear strength parameters of soil in the landslide zone. Sieve analysis was performed to obtain the particle size distribution. The water content of a soil sample was determined by oven drying method. Direct shear test apparatus was used to determine the shear strength parameters which was done under two stages in which normal stress (or confining pressure) was applied to the specimen at first stage and at the second stage, shear stress (or deviator stress) was applied to the specimen to shear it. The saturated density of soil sample was also calculated.

Using the shear strength parameters (c and $\varphi$ ), saturated unit weight ( $\Upsilon$ sat), submerged unit weight ( $\Upsilon$ sub), slope angle and depth of sliding surface, the stability analysis of slope were performed along the slope. Factor of safety for different zones were evaluated. The factor of safety for analysis of infinite slope of cohesive soil with steady seepage flow along the slope was calculated for each zone by using the formula as follow.

$\mathrm{FOS}=\left(\mathrm{c}+\Upsilon \operatorname{sub} H \cos ^{2} \mathrm{i} \tan \varnothing\right) / \Upsilon$ sat $\mathrm{H} \operatorname{cosi}$ sini

where, $\mathrm{c}=$ cohesion of soil sample,

$\Upsilon \mathrm{sub}=$ submerged density of soil

$\Upsilon$ sat $=$ saturated density of soil sample

$\mathrm{H}=$ depth of sliding surface

$\mathrm{i}=$ slope angle

$\varphi=$ angle of internal friction

Draught factor was determined based on (i) Slope angle, (ii) Stoniness, (iii) Altitude, (iv) Aspect, and (v) Annual rainfall. Slope scores were then provided to a site under consideration under these headings which were then added to obtain the draught factor (Mercy Corps Nepal, 2014). These all five aspects are measured as checklist and given the scores. The individual scores are then added accordingly to get a number, which define the site conditions. For the optimal bioengineering techniques, class I, II and III are considered as damp sites whereas class IV, V and VI are considered as dry sites. Major factors determining the optimal techniques for soil bio-engineering are slope angle, slope length, material drainage, site moisture, potential problem and function required. The optimal bio-engineering technique given by Mercy Corps Nepal, 2014, has been used for slope stabilization. Selection of plant species depend on the engineering function that plant need to perform as per site requirement. The ultimate process followed while selecting plant species is associated with various factors as site environment conditions, availability of materials, vegetation available, choice of vegetation, human factors, engineering and structural functions required.

\section{Results and Discussion}

\subsection{Inventory}

Google Earth images (Figure 2) show that till 2013 there was no sign for the formation of gully or occurrence of landslide. Large scale mass sliding started since 2015 and progressively went on increasing. The image of 2017 shows large scale mass sliding, which was triggered by the Gorkha earthquake and monsoon rainfall. The occasional torrential rains have caused landslide problems, especially to the areas in close proximity to the rural roads. The formation of gullies started adjacent to the present landslide. If timely preventive measure is not taken, possibilities of other large scale landslides cannot be ruled out. 

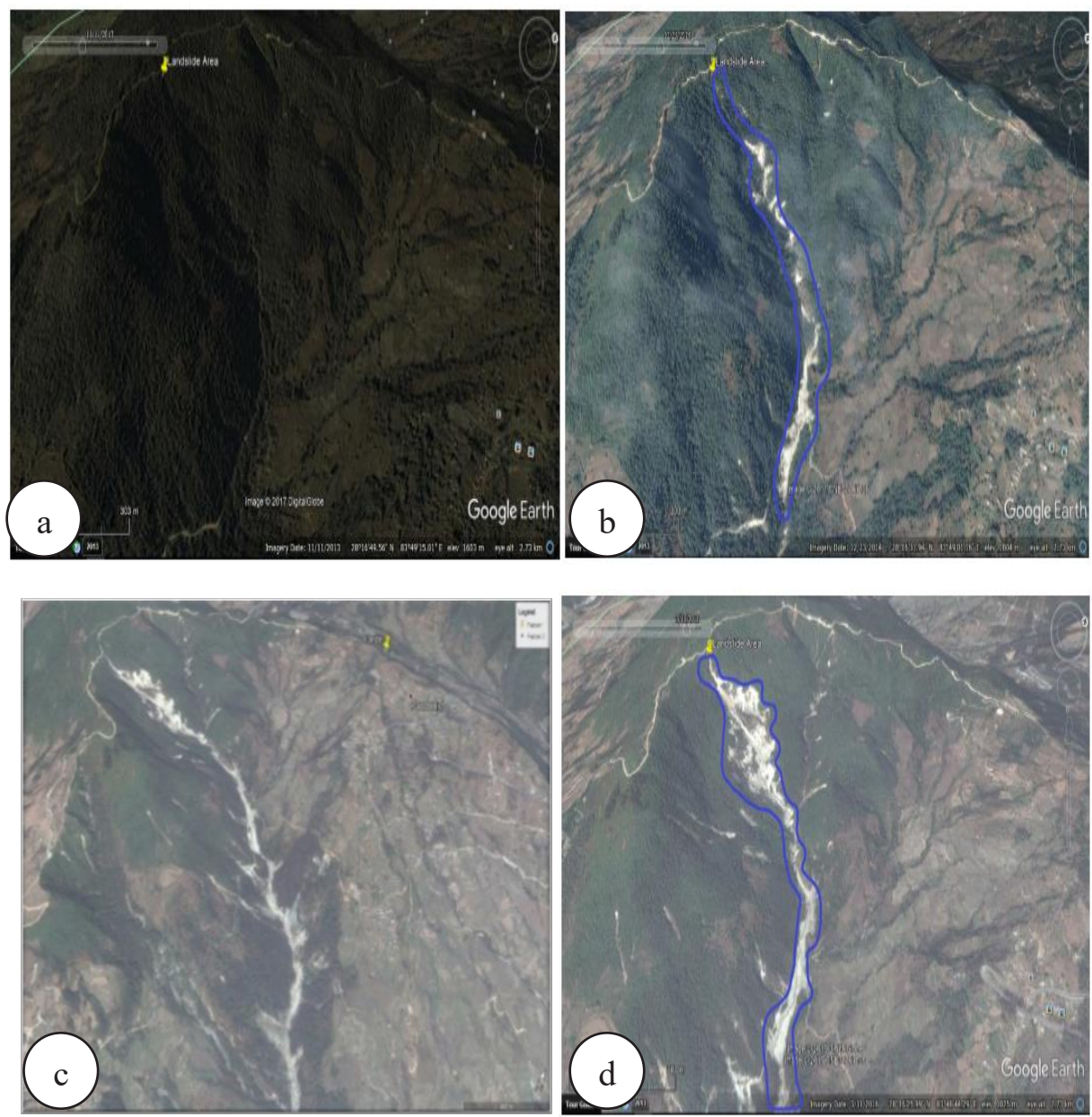

Figure 2: a) Google Earth image of the landslide area in 2013, b) formation of gully started in 2014 and progressively increased thereafter, c) Image of the landslide area in 2015 and d) The image of landslide area in 2017

\subsection{Slope Aspect of the Study Area}

Aspect determines the amount of direct sunlight that a site receives. The aspect map is prepared from geological map in a GIS environment. As shown in Figure 3, the upper portion of slope is facing towards East and North east whereas lower edge portion towards North and Southeast.

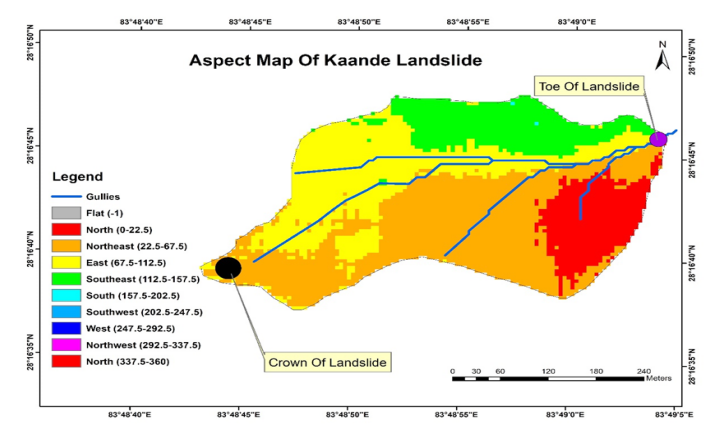

Figure 3: Slope aspect map of the Kaande landslide 
Nepal Engineers' Association, Gandaki 4.3 Land Use Pattern of the Study Area Land use is also one of the key factors responsible for the occurrence of landslides. The land use information of the study area has been adopted from the field visits. A sample picture taken during the field visit is presented in Figure 4. Rural roads are constructed both on the crown and toe part of landslide. The land use pattern in the study area is mainly characterized by the presence of forest, barren and cultivated land. It has moderately steep (15-25 $5^{\circ}$ at toe part) to steep slopes (up to $60^{\circ}$ at crown portion) as well.

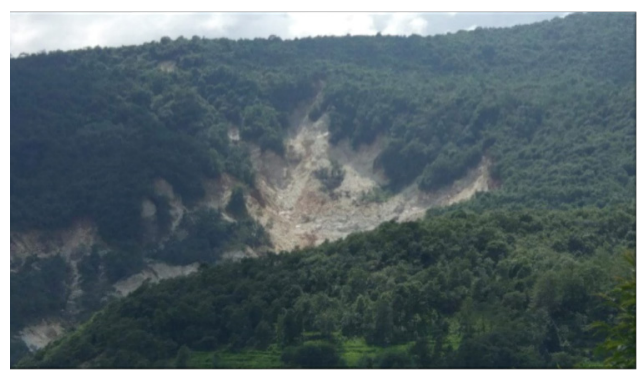

Figure 4: Landslide showing land use pattern of the study area

\subsection{Landslide Zoning}

Being different nature of slope conditions, soil/rock properties and for the application of engineering mitigation measures, entire landslide area has been divided into eight zones based on the parameters like soil/rock type, slope angle, failure mechanism, spring source, surface flow etc. The landslide zones are shown in Figure 5. The landslide zoning of entire area has been sketched as shown in Figure 6 .

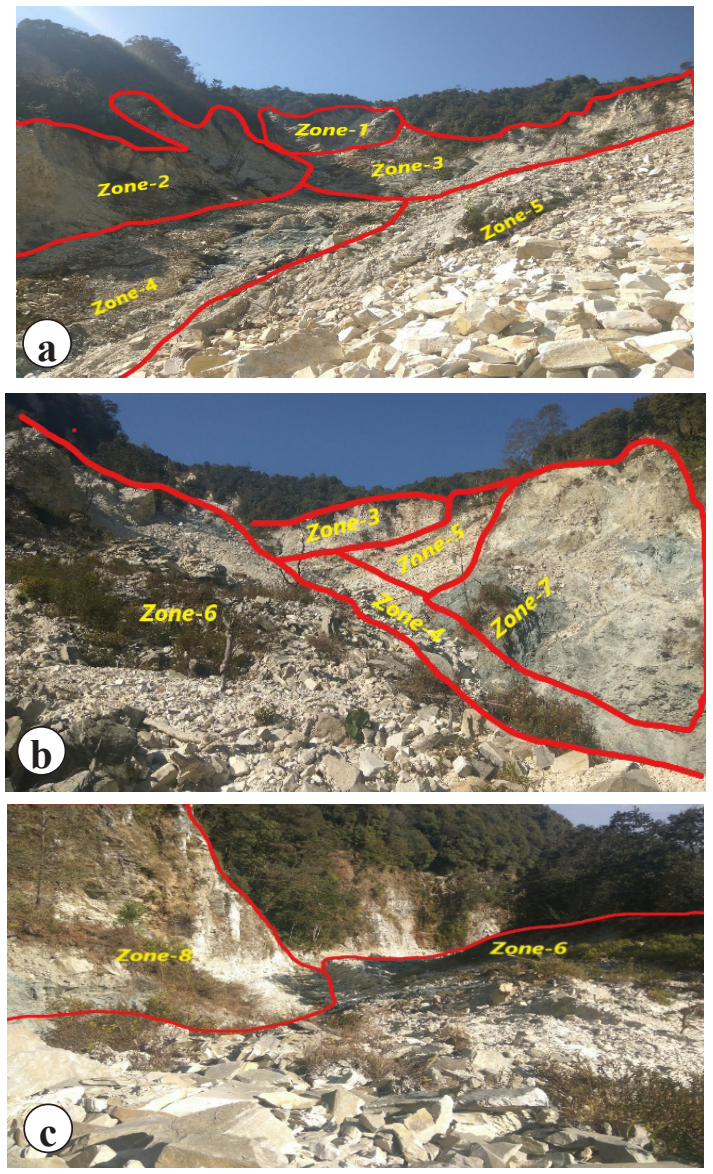

Figure 5: Landslide zonation images: a) crown and body part; b) body part and c) toe part

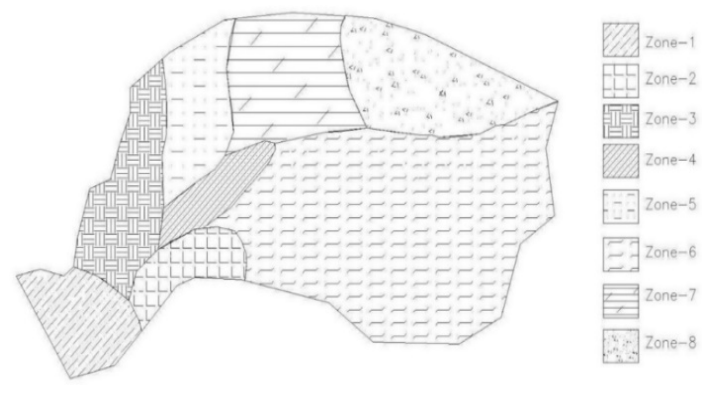

Figure 6: Landslide zonation sketch

\subsection{Laboratory Findings}

\subsubsection{Sieve Analysis}

The sieve analysis of soil from seven different zones in the landslide area was found to have coarse grained soil as shown in Table 1. 
Table 1: Lab results of sieve analysis

\begin{tabular}{|l|l|l|l|l|l|l|}
\hline Zone & Sample No. & Gravel \% & Sand \% & Fines \% & Gradation & Remarks \\
\hline I & A2 & 34.01 & 63.23 & 2.76 & Well graded gravel & Coarse grained \\
\hline II & B2 & 33.95 & 63.13 & 2.92 & Well graded sand & Coarse grained \\
\hline III & C2 & 56.13 & 29.28 & 14.59 & Gap graded & Coarse grained \\
\hline IV & D2 & 35.47 & 61.64 & 2.89 & Gap graded & Coarse grained \\
\hline V & E2 & 40.94 & 43.58 & 15.48 & Gap graded & Coarse grained \\
\hline VI & F2 & 58.31 & 28.16 & 13.54 & Gap graded & Coarse grained \\
\hline VII & G2 & 58.15 & 36.99 & 4.86 & Gap graded & Coarse grained \\
\hline
\end{tabular}

\subsubsection{Moisture Content}

Moisture content of the landslide area has varied from $11.53 \%$ to maximum of $17.08 \%$. When soil gets fully saturated, the potential of slope failure increases with increase in the moisture content. The saturated density of the samples taken from the site was observed to have an average value of $20.22 \mathrm{~kg} / \mathrm{m}^{3}$ and submerged density of soil samples as $10.41 \mathrm{~kg} / \mathrm{m}^{3}$.

\subsubsection{Direct Shear Test}

The shear strength parameters obtained from laboratory results are illustrated in Table 2 . The result shows that the soil has low cohesion i.e. the soil has coarse grained structure dominant having low binding among soil particles, which increases the possibility of slope failure.
Table 2: Lab results for shear strength

parameters of soil samples

\begin{tabular}{|c|c|c|c|c|c|}
\hline $\begin{array}{c}\mathscr{E} \\
\stackrel{0}{N}\end{array}$ & $\begin{array}{l}\dot{0} \\
Z \\
0 \\
0 \\
\tilde{\Xi} \\
\tilde{\Xi}\end{array}$ & 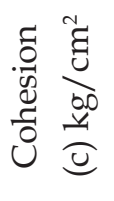 & 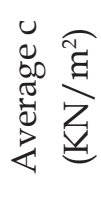 & 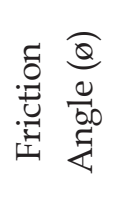 & 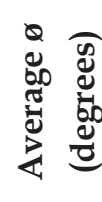 \\
\hline \multirow{3}{*}{ I } & A1 & 0.026 & \multirow{3}{*}{2.96} & 32.21 & \multirow{3}{*}{$31.79^{\circ}$} \\
\hline & A2 & 0.023 & & 32.62 & \\
\hline & A3 & 0.040 & & 33.02 & \\
\hline \multirow{3}{*}{ II } & B1 & 0.020 & \multirow{3}{*}{2.66} & 33.02 & \multirow{3}{*}{$32.47^{\circ}$} \\
\hline & B2 & 0.030 & & 31.79 & \\
\hline & B3 & 0.030 & & 32.62 & \\
\hline \multirow{3}{*}{ III } & C1 & 0.090 & \multirow{3}{*}{9.76} & 29.68 & \multirow{3}{*}{$29.53^{\circ}$} \\
\hline & $\mathrm{C} 2$ & 0.087 & & 30.11 & \\
\hline & C3 & 0.116 & & 28.81 & \\
\hline \multirow{3}{*}{ IV } & D1 & 0.030 & \multirow{3}{*}{3.00} & 32.21 & \multirow{3}{*}{$31.76^{\circ}$} \\
\hline & D2 & 0.020 & & 31.79 & \\
\hline & D3 & 0.040 & & 31.38 & \\
\hline \multirow{3}{*}{ V } & E1 & 0.123 & \multirow{3}{*}{10.87} & 29.25 & \multirow{3}{*}{$29.82^{\circ}$} \\
\hline & E2 & 0.090 & & 29.68 & \\
\hline & E3 & 0.113 & & 30.54 & \\
\hline \multirow{3}{*}{ VI } & F1 & 0.093 & \multirow{3}{*}{9.22} & 26.56 & \multirow{3}{*}{$27.46^{\circ}$} \\
\hline & F2 & 0.100 & & 28.37 & \\
\hline & F3 & 0.083 & & 27.47 & \\
\hline \multirow{3}{*}{ VII } & G1 & 0.060 & \multirow{3}{*}{4.89} & 33.43 & \multirow{3}{*}{$33.88^{\circ}$} \\
\hline & G2 & 0.046 & & 32.2 & \\
\hline & G3 & 0.040 & & 33.02 & \\
\hline
\end{tabular}




\subsubsection{Calculation of Factor of Safety}

The factor of safety (FOS) for analysis of infinite slope of cohesive soil with steady seepage flow along the slope is calculated for each zone by using equation 1 . The slope angle and sloping length measured in the field were used to calculate the depth of sliding surface as illustrated in Table 3 which shows that the slope is unstable. The factor of safety is remarkably low. The results indicate that the zones I, III, V, VI and VII are very much fragile and the slope seem to be highly unstable. Besides these, rest of two zones also exhibits unstable property of slope. There are further possibilities of occurrence of landslide and soil erosion. So, slope stabilization is urgently required.

Table 3: Slope geometry of landslide zones

\begin{tabular}{|l|l|l|l|l|l|}
\hline Zone & $\begin{array}{l}\text { Slope angle } \\
\left(\mathrm{i}^{\circ}\right)\end{array}$ & $\begin{array}{l}\text { Slope length, } \\
\mathrm{L}(\mathrm{m})\end{array}$ & $\begin{array}{l}\text { Depth of sliding } \\
\text { surface, } \mathrm{H}=\mathrm{L} \text { sini }(\mathrm{m})\end{array}$ & FOS & Stable/Unstable \\
\hline I & 50 & 80 & 61.28 & 0.281 & Unstable $($ FOS $<1)$ \\
\hline II & 35 & 30 & 17.20 & 0.511 & Unstable $($ FOS $<1)$ \\
\hline III & 36 & 75 & 44.08 & 0.412 & Unstable (FOS $<1)$ \\
\hline IV & 25 & 55 & 23.24 & 0.710 & Unstable $($ FOS $<1)$ \\
\hline V & 40 & 45 & 28.92 & 0.364 & Unstable $($ FOS $<1)$ \\
\hline VI & 38 & 70 & 43.09 & 0.376 & Unstable $($ FOS $<1)$ \\
\hline VII & 52 & 35 & 27.58 & 0.281 & Unstable $($ FOS $<1)$ \\
\hline
\end{tabular}

\subsection{Draught Factor}

The measurement of different parameters based on draught factor for selection of plants is shown in Table 4. Score for the five aspects were given according to their weightage defined by Mercy Corps Nepal, 2014. Draught factor is the total score obtained by adding the individual aspect score. Again based on the Stoniness (presence of fines) \%, the material drainage was classified as poor $(>15 \%)$ and good $(<15 \%)$ as follows. The Zones I and VII were found to be dry whereas others were damp. It has been observed that Zone V possessed poor material drainage whereas all the other zones had good material drainage.

\subsection{Soil Bio-engineering Mitigating Measures}

Soil bio-engineering mitigating measures are recommended for each zone as per the site requirement based on guidelines provided by Mercy Corps Nepal, 2014. The zone wise mitigating measures of Kaande landslide referring Table 3 are explained below:

\section{Zone I}

The zone has highly fractured rock at the lower portion and colluvium soil at the upper portion. Horizontal grass plantation is recommended.

Suitable grasses: Amliso (Thysanolaena maxima), Kans (Saccharum pontaneum) and Tite nigalo bans (Drepanostachyum intermedium).

Rooted stem cuttings of Amliso and Tite Nigalo bans are recommended to plant in line across the slope since they are large clumping and large spreading grass.

Plant to plant spacing is $1 \mathrm{~m}$ and row spacing of $0.25 \mathrm{~m}$ centre to centre. 


\section{Zone II}

Fractured rocks and colluvium soil with possibility of small shallow failure and soil erosion is dominant in this zone. Horizontal bolster cylinders and plantation of trees/shrubs are recommended.

\section{- Horizontal Bolster Cylinders}

They prevent surface scour and gullying (by reinforcing and fulfilling an intermittent armoring function), and provide shallow support.

Spacing: Two meters centre to centre.

\section{- $\quad$ Shrub and Tree Planting}

Shrubs or trees are planted at regular intervals on the slope. As they grow, they create a dense network of roots in the soil. The main engineering functions are to reinforce and, later, to anchor. In the long term, large trees provide slope support. The spacing of plants should be one meter centre to centre.

Suitable shrubs: Bains (Salix tetrasperma), Namdi phul (Colquhounia coccinea), and Simali (Vitex negundo).

Suitable trees: Chilaune (Schima wallichi), Utis (Alnus nepalensis), and Lankuri (Fraxinus floribunda).

\section{Zone III}

Deposited landslide debris consisting of colluvium deposit followed by down slope failure; perennial spring is observed here. Horizontal bolster cylinders and brush layering are recommended.

\section{- Brush Layering}

Woody (or hardhood cuttings) is planted in lines across the slope following the contour. These form a strong barrier, preventing the development of rills, and trap material moving down the slope. In the long term, a small terrace will develop.

Suitable plant species: Bains (Salix tetrasperma), Namdi phul (Colquhounia coccinea), and Simali (Vitex negundo).

\section{Zone IV}

Zone IV has been found with exposed phyllite (greenish) rock and through this section perennial spring passes Site seeding of grass and plantation of shrubs/trees are recommended.

\section{- $\quad$ Grass Seeding}

Grass is sown direct on to the site. It allows easy vegetation coverage of large areas. This technique is used in conjunction with mulching and jute netting to aid establishment. Jute net hold mulch on slopes that have been seeded, and serves no engineering function itself.

Suitable grass: Phurke (Arunduella nepalensis), and Amliso (Thysanolaena maxima).

They grow well on relatively damp slopes. They are tough and colonise landslides, therefore growing in harsh, stony sites and damper areas of forests.

\section{Zone V}

Deposited landslide debris consisting of colluvium deposit and boulders was observed in this zone. Plantation of shrubs/ trees and Herringbone bolster cylinders are recommended.

\section{- Herringbone Bolster Cylinders}

A main bolster runs straight down the slope with others running into it at an angle of $45^{\circ}$ to the fall of the slope (the herringbones or branches). The main bolster spines should run straight up to the top of the slope every 7.1 $\mathrm{m}$ along the slope. From the base of the main bolster, every $3 \mathrm{~m}$ above it, other herringbone 
Nepal Engineers' Association, Gandaki bolsters run at $45^{\circ}$ to the main bolster.

\section{- Shrubs/Trees Planting}

In between the gabion wire bolster networks, it is recommended to plant shrubs and trees raised in polythene pots. The planting of trees and shrubs help restore the natural vegetation on the slope to be treated.

Suitable shrubs/trees: Utis (Alnus nepalensis), Rato siris (Albizia julibrissin), Lankuri (Fraxinus floribunda), and Chilaune (Schima wallichii)

Since Utis and Chilaune are present in the sites, it is recommended to plant Utis and Chilaune to restore the natural vegetation.

\section{Zone VI}

Zone VI was found to have a very thick unconsolidated colluvium deposit. Horizontal bolster cylinders and brush layering is recommended.

In between the contour bolster cylinders brush layering is recommended. It provides a strong barrier, preventing the development of rills, and trap material moving down the slope. It catches the debris, armour and reinforces the slope.

Suitable plant species: Bains (Salix tetrasperma), Namdi phul (Colquhounia coccinea), and Simali (Vitex negundo).

\section{Zone VII}

Weathered rock mass; surface erosion due to weathering was observed here. Site seeding of shrubs and horizontal line of grass plantation is recommended.

Suitable shrubs: Simali (Vitex negundo), and Keraukose (Indigofera atroturpurea).

It is recommended to sow Keraukose and Simali direct to site. They colonise landslides.

\section{Zone VIII}

This zone has intact rock mass and seems most stable section. Being this section very stable, no soil bio-engineering measures are required here.

\section{Conclusion}

The whole landslide area was divided into eight zones starting from the crown to the toe for which the factor of safety of each zone was calculated based on stability analysis of an infinite slope of cohesive soils. The factor of safety of the landslide varied from 0.281 to 0.710 which revealed that the Kaande landslide was unstable and has possibilities of landslides and soil erosion in the future. For mitigating the hazard, slope stabilization is urgently required. Soil Bioengineering - an ecofriendly technique of slope stabilization is recommended for slope stabilization, which is an effective tool for treatment of a variety of unstableand/ or eroding sites. It is a better alternative for traditional civil engineering structures. Moreover, an increased environmental consciousness and sustainable development approach makes it more acceptable.

The Kaande landslide area is located geologically in the Lesser Himalaya, Western Nepal, and just south of the Main Central Thrust (MCT). The landslide has been triggered by the Gorkha Earthquake of April, 2015 and subsequent heavy rainfall of July, 2015 with continuing movement in every monsoon. The slope at present in Kaande area was observed to be unstable and there is a further possibility of land sliding and soil erosion in the future. Haphazard construction of rural roads in forest areas is one of the reasons of many landslides. That is why in landslide prone area and its proximity, it is recommended to prepare 
guidelines for excavation and construction of civil engineering structures.

\section{References}

Basnet, K., and Acharya, D., 2019. "Flood analysis at Ramghat, Pokhara, Nepal using HEC-RAS", Technical Journal, vol. 1 (1), pp. 41-53. https://doi.org/10.3126/ tj.v1i1.27591.

Crozier, M. J., 1986, "Landslides: Causes, Consequences and Environment", Croom Helm, London, vol. 7, pp. 1-110.

Crozier, M. J., and Glade, T., 2005, "A review of scale dependency in landslide hazard and risk analysis", in Glade, T., Anderson, M. G., and Crozier, M. J. (editors), On Landslide hazard and risk, Chichester, Wiley.

Dahal, R. K., Hasegawa, S., Nonomura, A., Yamanaka, M., and Masuda, T., 2008, “GISBased Weights-of-Evidence Modelling of Rainfall-Induced Landslides in Small Catchments for Landslide Susceptibility Mapping", Environmental Geology, vol. 54, pp. 11-24.

Dai, F. C., Lee, C. F., Li, J., and Xu, Z. W., 2001, "Assessment of landslide susceptibility on the natural terrain of Lantau Island, Hong Kong", Journal of Environmental Geology, vol. 40, pp. 381-391.
Deoja, B., Dhital, M. R., Thapa, B., and Wagner, A., 1991, "Mountain risk engineering handbook", ICIMOD, Kathmandu, vol. 857.

Devkota B. D., Paudel P., Omura H., Kubota T., and Morita K., 2006, "Uses of vegetative measures for erosion mitigation in mid hill areas of Nepal", Kyushu J For Res, vol. 59, pp. 265-268.

Ercanoglu, M., Gokceoglu, C., and Van Asch W.J., 2004, "Landslide Susceptibility Zoning North of Yenice (NW Turkey) by Multivariate Statistical Techniques", Natural Hazards, vol. 32, pp. 1-23.

Larsen M. C. and Torres-Sanchez A. J., 1998, "The frequency and distribution of recent landslides in three montane tropical regions of Puerto Rico", Geomorphology, vol. 24, pp. 309-331.

Mercy Corps Nepal, 2014, "Bio-engineering for River Training and Slope Protection Work: Training Manual for field technicians working in disaster risk reduction", Mercy Corps, Lalitpur, Nepal.

Pokharel, S., 2008, "Lessons from Nepal on developing a strategic plan for the Integrated Lake Basin Mgmt", Conservation of Phewa Lake of Pokhara, Nepal. 